\title{
PEMIKIRAN TAFSÎR MESIR MODERN J.J.G JAN SEN \\ (Telaah atas Karya J.J.G.Jansen The Interpretation of The Koran in M odern Egypt)
}

\author{
A bu Bakar \\ (D osen U shuluddin STA IN Ponorogo)
}

\begin{abstract}
A bstract:
Jansen is a researcher that classifies the work of interpretation (tafsîr) into: firstly, an interpretation adopting a modern science but not oppose against the holy Quran, it is called tafsîr al-'ilmî. Secondly, an interpretation that is designed to help reader understand the holy Quran or philological interpretation (altafsîr al-lughawî). Thirdly, an interpretation dealing with the Muslim deed and it is called practical interpretation (tafsîr aladabî al-ijtimâ'î). Jansen is about to display a short description that covers the answers of explanation inadequacy of the previous researchers' studies. He mainly clarifies the history of interpretation and western studies on interpretation developing in Islamic world. As a matter of fact, Jansen's view is majorly a kind of beginning critical of his attention on interpretation. He focuses the research object on the interpretation of Muhammad Abduh, then he compares it to the other intrepretations that are considered up to standard to be classified into his work of interpretation.
\end{abstract}

Key Words:

al-Qur'ân, tafsîr, dan Jansen

\section{Pendahuluan}

Kitab suci, dalam suatu komunitas ummat beragama, telah menjadi topik perbincangan secara akademik, baik oleh pemeluknya maupun ummat lain yang menelaahnya. Kondisi ini juga menimpa umat Islam, di mana al-Qur'ân sebagai kitab suci kaum muslimin, dalam kodifikasinya merupakan hasil dari proses panjang melalui beberapa generasi, kemudian muncul teks standar sebagai pedoman pencetakan kitab suci ini. Proses stadarisasi teks al-Qur'ân seperti ini 
kemudian dikenal dengan sejarah al-Qur'ân (târîkh al-Qur'ân).1 Pembicaraan tentang sejarah teks ini melibatkan beberapa hal, yaitu tentang susunan surat dalam ayat, serta pengkodifikasian teks alQur'ân menjadi mushhaf U tsmânî berikut penyempurnaann tanda baca yang ada seperti mushhaf sekarang. ${ }^{2}$

Sejarah teks al-Qur'ân yang menjadi objek kajian para sarjana Barat telah dimulai sejak abad ke-12 $\mathrm{M}^{3}$ dan telah melahirkan banyak karya kesarjanaan. ${ }^{4}$ Secara umum, sasaran kritik Barat terhadap kemunculan mushhaf U tsmânî tertuju pada tiga fase. Pertama, koleksi dan susunan teks dari lisan sampai tulisan. Kedua, tentang perbedaan cara baca dan beberapa kodeks shahabat. Ketiga, proses pemantapan teks dan cara baca menjadi kanonik.

Selanjutnya, para sarjana Barat selain meneliti tentang teks alQur'ân, mereka melakukan pengkajian pula terhadap penafsiran kaum muslim terhadap teks al-Qur'ân (tafsîr). Dalam hal ini karya Ignaz Goldziher, Die Richtungen development Islamichen Koranauslegung (1920), telah berupaya mengungkapkan beberapa madzhab penafsiran yang ada semenjak munculnya tafsîr sampai periode Muhammad Abduh. ${ }^{5}$ Tetapi penelitian ini dianggap kurang "sempurna" oleh Jansen karena tidak lengkapnya kepustakaan yang digunakan oleh Barat. Hal ini telah mendorong Jansen untuk meneliti beberapa koleksi tafsîr al-Qur'ân, khususnya di Mesir.

\footnotetext{
${ }^{1}$ Ada beberapa karya sejarah Muslim yang membahas tentang târîkh al-Q ur'ân, di antaranya adalah: Abdullah al-Zanjani, Târîkh al-Qur'ân, (Kairo: al-Haya' alMisriyyah al-'A mmah li al-Kitab, 1935) dan A bd al-Qâdir al-Karadi, Târîkh al-Q ur'ân wa Gharâib R asmihi wa H ukmihi, (Kairo: Mushthafa al-Babi al-Halabi, 1953).

2 Muhammad Nur Kholis, Mengkaji Sejarah Teks al-Qur'ân, Makalah Simposium Nasional “Perkembangan Pemikiran al-Qur'an" Yogyakarta, 26-28 Desember 1997.

3 Lihat W. Monthomery Watt, Bell's Introduction to the Q ur'an, (Edinburg: Edinburgh University Press, 1970, hlm. 173.

${ }^{4}$ Karya-karya tersebut, di antaranya, adalah: Arthur Jeffery, $\mathrm{M}$ aterials for the $\mathrm{H}$ istory of the Text of the Q ur'an; the O Id Codices, (Leiden: E.J. Brill, 1937), The Q ur'an as Scripture, New York: Russel F. Moore Company, 1952); W. Montgomery Watt, Bell's Introduction, dan John Burton, The Collection of the Qur'an, (Cambridge: Cambridge University Press, 1977).

5Karya Goldziher ini cenderung untuk lebih meneliti pada content dan kecenderungan penulis, dengan tidak berpijak pada periodisasi waktu. Kekurangan lain dari karyanya adalah bahwa ia tidak melakukan pengamatan kepada seluruh tafsîr, di antaranya karya al-Mahallî dan al-Suyûthî, al-Jalâlayn, yang menjadikan kajiannya "kurang" sempurna.
} 
Perikiran Tafsîr Mesir Modern J .J .GJ ansen

\section{Barat dan Kajian al-Q ur'ân}

Di Barat, kajian al-Qur'ân menjadi salah satu alternatif kajian akademik yang menarik banyak perhatian, mulai dari sarjana muslim hingga non muslim. Kajian al-Qur'ân di Barat menyangkut berbagai aspek, mulai dari teks al-Qur'ân itu sendiri, penafsiran para sarjana muslim baik pada masa klasik hingga masa modern saat ini.6Salah satu karya sarjana Barat yang memfokuskan pada karya-karya tafsîr adalah Ignaz Goldziher dalam masterpiece-nya Die Ricchatungen der Islamischen Koranauslegung yang ditulis pada 1920. Dalam karya yang monumental ini, sang sarjana mampu menyajikan enam bilik diskursus terhadap dunia tafsîr.

Bilik pertama, masalah keberadaan tafsîr pada masa awal. Tafsîr pada masa ini bernuansa teologis yang direpresentasikan dengan berbagai aliran. Aliran-aliran tersebut didasarkan pada faktor pembacaan teks mulai dari aspek oral hingga kesaksian sejarah. Juga disajikan reportasi perkembangan bacaan yang terjadi pada saat ini disusul dengan munculnya penyusunan gramatikal al-Qur'ân.

Bilik kedua, menyajikan gaya dan corak pendekatan tafsîr. Hal ini diklasifikasikan menjadi dua; yaitu tafsîr bi al-ma'tsûr dan tafsîr bi al-ra'yi beserta tokoh dan propagandisnya. Pada bilik ini semakin jelas metode, corak, dan madzhab yang digunakan oleh mufassir pada masa awal sebagai penguat ideologinya.

Bilik ketiga, tentang pengembangan tafsîr pasca periode awal, yaitu pasca teologis yang menghasilkan era post teologis. Era ini ditandai dengan perubahan teologi menjadi teologi rasional yang juga disertakan berbagai tokoh dan propagandisnya.

Bilik keempat, menyajikan perkembangan tafsîr yang berangkat dari doktrin menuju rasional. Ketika mencapai titik kulminasi, akhirnya menghasilkan era kesadaran jiwa yang disimbulkan dengan karya-karya tafsîr yang bernuansa sufistik serta berbagai tokoh dan propagandis tafsîr sufi.

Bilik kelima, memaparkan tafsîr dalam perspektif sekte keagamaan. Dalam bilik ini disajikan secara spesifik tafsîr sekte-sekte keagamaan dengan jelas. Dalam era ini sekte keagamaan yang semula

${ }^{6}$ J.J.G. Jansen, The Interpretation of the K oran in M odern Egypt (Leiden: E.J. Brill, 1980), hlm. 8 
dipandang sebagai sesuatu yang tidak umum, kini mulai dianggap lumrah keberadaannya.

Bilik keenam, penulis menelaah tafsîr pada masa kebangkitan Islam. Pada era ini semakin terbuka diskursus tentang al-Qur'ân. Kalau pada era sebelumnya hanya dipetakan antar sekte, kini dalam sekte itu sendiri telah terjadi keterbukaan dan kejelasan madzhab masing-masing. ${ }^{7}$

\section{Pandangan Jansen tentang Tafsîr di M esir M odern}

Karya Jansen berjudul The Interpretation of The Koran in M odern Egypt adalah disertasi doktoralnya di Rijksuniversiteit Leide tahun 1972. Kajiannya memusatkan pada keseluruhan karya tafsîr di Mesir modern. Buku setebal 111 halaman yang diterbitkan oleh E.J. Brill tahun 1980, berisi beberapa bab, yaitu: bab pertama, Introduction: The Koran and its Interpretation. Bab kedua, Mohammad A bduh's Koran Interpretations. Bab ketiga, Koran Interpretation and Natural History. Bab keempat, Koran and Interpretation and Philology, dan bab kelima, Practical Koran Interpretation

Beberapa alasan yang dikemukakan Jansen dalam memilih penelitian yang dikonsentrasikan di Wilayah Mesir.8 Pertama, modernisasi pemikiran Islam tidak bisa dipisahkan dari proposal pembaruan "Abduh" yang sekaligus melakukan renovasi besarbesaran terhadap kajian al-Qur'ân. Kedua, banyaknya koleksi termasuk di antaranya al-Tafsîr al-Bayânî li al-Q ur'ân al-Karîm, satusatunya tafsîr yang ditulis mufassir wanita, yakni 'Aisyah Abd alRahmân yang dikenal dengan sebutan Bint al-Syâthi'. Ketiga, mulai akhir dekade 60-an, Leiden mempunyai J. Brugman, spesialis budaya dalam sastra Timur Tengah yang melahirkan doktor-doktor muda untuk spesialisasi wilayah Mesir dan sekitarnya, di mana Jansen merupakan salah satu di antaranya.

Jansen membagi karya tafsîr ke dalam tiga kelompok. Pertama, tafsîr yang mengadopsi ilmu pengetahuan modern yang tidak bertentangan dengan al-Qur'ân, disebut dengan tafsîr al-'ilmî. Kedua, tafsîr yang diperuntukkan untuk membantu pembaca dalam

7 Ignaz Goldziher, M adzâhib al-T afsûr al-Islâmî, (Beirut: Dâr al-Iqra', 1983), hlm.354.

8 Lihat penjelasan Muhammad Nur Kholis dalam pengantar terjemahan karya J.J.G. Jensen, D iskursus Tafsîr M odern, (Yogyakarta: Tiara Wacana, 1997), hlm. xii. 
memahami al-Qur'ân, yang disebut dalam kelompok tafsîr filologis (al-tafsîr al-lughawî). Ketiga, tafsîr yang bersinggungan dengan perbuatan umat Islam, yang disebut dengan tafsîr praktis (tafsîr alA dabî al-Ijtimâ'i).

Karya Jansen menampilkan suatu deskripsi yang singkat namun memiliki cakupan luas yang bisa menjawab kekurangankekurangan karya-karya pendahulunya. $\mathrm{Hal}$ ini tergambar dalam paparannya pada bab pertama: Introduction: The Koran and Interpretation, ia begitu banyak menjelaskan sejarah tafsîr, serta studistudi orang Barat terhadap tafsîr yang berkembang di dunia Islam. Sehingga tidak begitu aneh bila ia benar-benar ingin menemukan sesuatu yang baru dari studi tafsîr yang belum dibahas dan luput dari pemahaman para pendahulunya.

Dalam upayanya ini, Jansen memberikan satu kritik awal dari perhatiannya kepada tafsîr, yaitu dengan memusatkan objek penelitian kepada tafsîr Abduh untuk kemudian dibandingkan dengan tafsîr-tafsîr lain yang dia anggap memenuhi persyaratan untuk masuk kepada pembagian yang diberikannya.

Sebagai landasan argument Jansen terhadap upayanya dalam memfokuskan objek kajiannya terhadap karya Muhammad Abduh adalah sebagai berikut:

To quote Abduh: On The Last Day God will not question us on the opinions of the commentators and on how the understood the Koran, but he will question us on his Book which he sent down to guide and instruct us. A bduh intended to explain the Koran in a practical manner to a public wider than merely the professional theologians, and Egyptian public that according to the modern M oslem apologists - lacked competent religious leader, suffered from foreign (British) occupation, did not understand the technical science and among whom superstition and become predominant. Abduh tries to make his readers, laymen and theologians alike, realize the limited relevance of the traditional commentaries that do not contribute to the solution of the urgent problem of the day. He wishes to convince them that them that they should allow the Koran to speak for it self, un obscured by subtle explanations and glosses. ${ }^{9}$

Dalam pandangan Jansen, tidak ada tafsîr-tafsîr al-Qur'ân baru yang muncul di Mesir pada abad ke-19. Abduh dan Ridlâ, sejak

9 Jansen. The Interpretation, hlm. 19. 
itu, meratakan jalan bagi kemunculan sejumlah besar tafsîr abad ke19. Dalam membangun kembali pentingnya penafsiran al-Qur'ân mereka juga menetapkan suatu garis antara al-Qur'ân dan masalahmasalah kehidupan manusia di dunia ini. Hal ini dilakukan Abduh dengan membuang bobot pengetahuan tafsîr klasik yang terlalu membebani para pembacanya. la mengisi ruang itu dengan memberikan nasihat-nasihat pendek yang praktis, bijaksana, arif dan mencerahkan bagi problem-problem masyarakat Mesir pada zamannya. Terutama sekali, ia menekankan kebutuhan akan pendidikan, karena hanya dengan pendidikan masyarakat Mesir bisa meletakkan posisi mereka untuk mengusir penjajah asing.

Bila sebelumnya telah dijelaskan bahwa karakteristik tafsîr lebih menempatkan masalah akademis, yaitu tafsîr berisi penjelasan detail terhadap kata-kata teknis, tata istilah bahasa Arab, hukum dan dogma Muslim, sunnah Nabi dan para sahabatnya, dan biografi Nabi, lebih dari itu dalam tafsîr ini cenderung sebagai ensiklopedi dari ilmu-ilmu tersebut. Maka sosok Muhammad Abduh ingin menjelaskan bahwa sesungguhnya al-Qur'ân yang merupakan kitab petunjuk (hidâyah) perlu dipahami secara praktis. Pandangan inti didasarkan pada kondisi sosio-kultural penduduk Mesir yang "kering" akan nilai luhur akibat pandangan mereka yang masih mengikuti tradisi terhadap pemahaman al-Qur'ân. Oleh sebab itu A bduh ingin memberikan jawaban terhadap masalah-masalah dalam kehidupan dengan memahami al-Qur'ân secara praktis, sehingga alQur'ân benar-benar menjadi hidâyah.

Dalam pandangan Jansen, tafsîr Abduh merupakan sesuatu yang baru dan orisinil. Selain menampakkan pikiran-pikiran baru, juga penekanannya yang baru dalam melihat al-Qur'ân, yakni sebagai sumber, petunjuk keagamaan dan spiritual, bukan pada dogma Islam, atau suatu ajang kesempatan bagi para filolog untuk memamerkan kepintaran mereka. Abduh menilai al-Qur'ân sebagai kitab yang seharusnya umat Islam bisa merumuskan pemikiran-pemikiran mengenai dunia ini dan dunia yang akan datang.

Sistem penafsiran Abduh, dalam pandangan Jansen, adalah keragu-raguannya dalam menerima materi dari luar al-Qur'ân itu sendiri sebagai sesuatu yang bermakna bagi penafsiran al-Qur'ân. Sedangkan kaidah penafsiran adalah bahwa seseorang seharusnya tidak perlu menjelaskan sesuatu yang memang sengaja tidak 
dijelaskan oleh al-Qur'ân, (mubham). Dengan demikian, seorang mufassir diwajibkan menjelaskan teks sebagaimana adanya dan tidak menambah-nambah. Oleh sebab itu, Abduh ketika dihadapkan pada penentuan makna ayat atau kata tertentu lebih banyak melihat konteksnya, tidak seperti ulama sebelumnya yang dibatasi pada penjelasan tradisional saja.

Abduh menolak otoritas dan validitas hadits-hadits tertentu yang diterima dari generasi Muslim awal. Ia tidak mengakui relevansi hadits-hadits itu terhadap penafsiran al-Qur'ân, khususnya pada hadits-hadits yang disebut dengan isrâilliyyât yang dibuat untuk meruntuhkan Islam. la mengaku berhak untuk menolak hadits apa pun yang tidak sesuai dengan pemahamannya terhadap Islam dan alQur'ân, entah itu hadits Isrâilliyyât atau pun bukan, karena menurutnya seseorang tidak seharusnya "menambah" terhadap teks al-Qur'ân.

Selanjutnya, Jansen melihat bahwa pandangan A bduh tentang tafsîr al-Qur'ân dan sejarah alam tidak sepenuhnya konsisten dengan pandangan-pandangannya yang lain. Di dalam suatu bagian yang terkenal dari tafsîrnya, Abduh berpendapat bahwa jin, roh-roh halus, dan orang pandai yang disebut di dalam al-Qur'ân dan penting dalam budaya (folklore) ummat Islam, bisa dipahami sebagai kumankuman. Di lain tempat, al-Qur'ân menyebutkan cahaya, Abduh mengupas tentang listrik, telegraf, telepon dan kereta api. Dengan melakukan hal demikian, ia juga bisa dituduh memasukkan ke dalam tafsîr al-Qur'ân materi yang tidak esensial begi petunjuk spiritual yang ingin disampaikan al-Qur'ân. Bagaimanapun, ia sebagaimana dilakukan para mufassir kemudian, tidak berpendapat bahwa makna secara aktual dirujuk oleh al-Qur'ân, atau bahwa makna riil al-Qur'ân hanya bisa dipahami setelah kuman-kuman dan listrik ditemukan. Tetapi lebih dari itu, Abduh ingin pembacanya menyadari bahwa Islam toleran dengan semua penemuan ilmiah, dan bahwa al-Qur'ân terlalu tinggi untuk dilawankan dengan ilmu pengetahuan modern, cara yang sama dengan yang dilakukan oleh teologi Kristen yang tidak memikirkan apakah informasi sejarah yang ada dalam Injil itu akurat atau tidak. Al-Qur'ân menurut Abduh bukan buku mengenai hukum, ilmu atau sejarah, tetapi firman Tuhan: "Pengetahuan kami 
tentang al-Qur'ân adalah pengetahuan kami tentang Allah".10 Pandangan umat Islam terhadap al-Qur'ân berbeda dengan pandangan Kristen dan Yahudi terhadap kitab sucinya. Umat Islam meyakini bahwa alQur'ân punya hubungan khusus dengan ilmu pengetahuan, artinya al-Qur'ân dijadikan rujukan sebagai sumber ilmu pengetahuan modern. Penelitian itu termasuk pemikiran Jansen terhadap banyak munculnya tafsîr 'ilmî di wilayah Mesir modern. Tafsîr itu mencoba memindahkan semua bidang pengetahuan kemanusiaan yang memungkinkan ke dalam penafsiran al-Qur'ân. Terutama apa yang dicap orang sebagai "sejarah alam" (natural history) yang menjadi fantasi para mufassir kontemporer yang bekerja di dalam aspek penafsiran al-Qur'ân.11

Penafsiran dengan pendekatan sejarah alam ini telah dimulai sejak masa I bnu Abbâs, dan sampai sebelum abad ke-19 tidak muncul dan tidak tersebar secara luas. Salah satu yang membela kebenaran tafsîr ini adalah al-Ghazâlî dalam Jawâhir al-Qur'ân. Ia mengajarkan bahwa al-Qur'ân hanya akan menjadi jelas bagi mereka yang mempelajari ilmu pengetahuan yang digali darinya. IImu pengetahuan bisa menjelaskan isi al-Qur'ân dengan cara seperti anakanak sungai yang lebih kecil yang memberikan air kepada sungai yang lebih besar.

Pada abad ke-19 kemunculan tafsîr 'ilmî begitu pesat. Sarjana pertama yang memberikan perhatian besar adalah Amin al-Khully (w.1967). Tafsîr-tafsîr yang menjadi perhatian Jansen adalah karya Muhammad Ibn A hrmad al-Iskandarani yang berjudul Kasyf al-A srâr al-Nuranniyah al-Qur'âniyah (1880) dan Tibyân al-A srâr al-Rabbâniyyah (1883), Tanthawî Jawhârî dengan al-Q ur'ân wa al-'U lûm al-'A shariyyah (1925) dan al-Jawâhir fî Tafsîr al-Q ur'ân al-Karîm al-M usytamil 'ala 'A jâibi Badâ'i al-M ukawwanât wa al-Gharâib al-A yât al-Bahîrat (1940), Karya Farid Wajdi Shaffât al-'Irfân dan Dâirah M a'ârif al-Q ur'ân Rab'i 'A shr al'I syrîn serta tafsîr lainnya yang muncul.

Munculnya tafsîr ilmiah adalah sebagai bentuk pengaruh modern yang berlangsung di dunia Islam dimana terjadi sejak awal pengaruh teknologi ilmu pengetahuan dan politik Barat di dunia

10 Jansen, The Interpretation, hlm. 33-34.

11 Legitimasi mereka tentang hubungan al-Qur'ân dengan ilmu pengetahuan adalah QS. al-Nahl (16): 89, al-An'âm (6): 38. 
Arab. Tetapi tidak semua pakar tafsîr di dunia Islam, khususnya kaum tradisionalis, menerima keberadaan tafsîr 'ilmi. Maka tidak jarang penolakan muncul terhadap keberadaannya. Sebagai contoh Amin al-khulli mengemukakan beberapa argumen untuk melawan tafsîr ilmiah, di antaranya adalah; Ketidakkokohan leksikologisnya, Ketidakkokohan secara filologis, serta ketidakkokohan secara teologis. Jadi al-Qur'ân tidak sesuai dengan fungsi dan kedudukannya sebagai hidayah.

Perhatian Jansen yang lain adalah banyak munculnya karakteristik tafsîr yang lebih memperhatikan perkembangan filologis, di mana selain dari segi bahasanya, nilai historis dari bahasa itu juga sangat diperhatikan. Tafsîr yang menjadi rujukan utamanya adalah tafsîr karya Bint Syâthi', seorang wanita yang suaminya adalah ahli tafsîr juga, sekaligus untuk memberikan porsi lebih kepada satu-satunya tafsîr dari kalangan wanita, yaitu Tafsîr al-Bayâni al-ljtimâ'î.

Sedangkan pada bab terakhir, Jansen ingin mencoba mendeskripsikan bentuk tafsîr yang cenderung ingin menyentuh persoalan-persoalan sosial, atau yang lebih dikenal dengan tafsîr aladabî al-ijtimâ'î. Tafsîr ini menekankan pada fungsi dan kedudukan alQur'ân, bahwa ia diturunkan kepada manusia tidak lain sebagai hidâyah. Oleh sebab itu, pernyataan Abduh terhadap para mufassir terdahulu dianggap telah memalingkan al-Qur'ân dari fungsi dan kedudukannya ketika ia diturunkan. Salah satu tafsîr yang dijadikan rujukan adalah karya Muhammad Musthafâ al-Marâghî, seorang murid Abduh yang dikenal dengan nama Tafsîr al-M arâghî, juga karya-karya dari Amin al-Khully, yang khususnya makalah-makalah yang dia sampaikan dalam siaran radio.

\section{Penutup}

Karya yang telah ditulis oleh Jansen, sebagai hasil penelitiannya untuk disertasi, mempunyai arti lebih, khususnya bagi para pemerhati tafsîr. Karya ini banyak menyibak persoalanpersoalan yang oleh sarjana sebelumnya tidak mendapat perhatian, baik itu dari sisi objek kajian, maupun metodologi yang digunakannya.

Pada abad modern ini, di mana Mesir masih menjadi kiblat munculnya karya-karya keislaman, telah mengalami banyak 
perubahan. Pada sisi metode penafsiran al-Qur'ân, para mufassir Mesir tidak lagi mengikuti trend masa lalu, di mana tafsîr seolah-olah buku akademis, atau ensiklopedi pengetahuan keislaman. Mereka ingin menempatkan al-Qur'ân sebagai wahyu yang mempunyai fungsi dan kedudukan sebagai hidâyah, yang bisa memberikan pengaruh dalam kehidupan ummat sehari-hari. Wallâh a'lam bi alShawâb.

\section{D aftar Pustaka}

Burton, John. The Collection of the Qur'an. Cambridge: Cambridge University Press, 1977

Goldziher, Ignaz. M adzâhib al-T afsîr al-Islâmî. Beirut: Dâr al-Iqra', 1983

Jansen, J.J.G. The Interpretation of The Koran in M odern Egypt. Leiden: E.J. Brill, 1980

Jeffry, Arthur. The Qur'an as Scripture. New York: Russel F. Moore Company, 1952.

-----. M aterials for the History of the Text of the Q ur'an; the O Id Codices. Leiden: E.J. Brill, 1937

Karadi, Abd al-Qâdir al-. Târîkh al-Qur'ân wa Gharâib Rasmihi wa Hukmihi. Kairo: Mushthafâ al-Bâbi al-Halalabi, 1953

Kholis, Muhammad Nur. M engkaji Sejarah Teks al-Qur'ân, Makalah Simposium Nasional "Perkembangan Pemikiran al-Qur'an" Yogyakarta, 26-28 Desember 1997

Watt, W. Montgomery. Bell's Introduction to the Qur'an. Edinburgh: Edinburg University Press, 1970

Zanjani, A bd Allâh al-. Târikh al-Q ur'ân. Kairo: al-Hayâ' al-Mishriyah al-'Amma li al-Kitâb, 1935. 